ARTICLE

https://doi.org/10.1038/s41467-019-10851-4

\title{
Facilitating the transmetalation step with aryl- zincates in nickel-catalyzed enantioselective arylation of secondary benzylic halides
}

\author{
Weichen Huang ${ }^{1}$, Mei Hu², Xiaolong Wan $^{1} \&$ Qilong Shen (1) ${ }^{1}$
}

Nickel-catalyzed asymmetric cross-coupling of secondary alkyl electrophiles with different nucleophiles represents a powerful strategy for the construction of chiral tertiary carbon centers. Yet, the use of aryl Grignard reagents or aryl zinc halides in many reactions typically resulted in low enantioselectivity, mainly due to their slow transmetalation step in the catalytical cycle and consequently the requirement of relatively high temperature. Here we report that the use of lithium aryl zincate $\left[\mathrm{Ph}_{2} \mathrm{ZnBr}\right] \mathrm{Li}$ facilitates the transmetalation step of the nickel-catalyzed cross-coupling reaction. Based on this discovery, a highly enantioselective construction of fluoroalkyl-substituted stereogenic center by a nickel-catalyzed asymmetric Suzuki-Miyaura coupling of $\alpha$-bromobenzyl trifluoro-/difluoro-/mono- fluoromethanes with a variety of lithium aryl zincates $\left[\mathrm{Ph}_{2} \mathrm{ZnBr}\right] \mathrm{Li}$ that were in situ generated from the reaction of lithium organoboronate with 1.0 equivalent of $\mathrm{ZnBr}_{2}$ was described.

\footnotetext{
${ }^{1}$ Key Laboratory of Organofluorine Chemistry, Shanghai Institute of Organic Chemistry, University of Chinese Academy Sciences, Chinese Academy of Sciences, 345 Lingling Road, 200032 Shanghai, People's Republic of China. ${ }^{2}$ Shandong Provincial Key Laboratory of Fluorine Chemistry and Chemical Materials, School of Chemistry and Chemical Engineering, Shandong Engineering Research Center for Fluorinated Material, University of Jinan, 250022 Jinan, China. Correspondence and requests for materials should be addressed to Q.S. (email: shenql@sioc.ac.cn) or (email: shenql@mail.sioc.ac.cn)
} 
$\mathrm{O}$ ver the past two decades, nickel-catalyzed asymmetric cross-coupling of secondary alkyl electrophiles with different nucleophiles has emerged as powerful methods for the construction of chiral tertiary carbon centers ${ }^{1-4}$. Since the seminar work by $\mathrm{Fu}$ and co-workers in $2005^{5}$, a number of activated racemic alkyl halides such as a-bromoamides ${ }^{5}$, a-bromoketones ${ }^{6}$, benzylic bromides and chlorides ${ }^{7,8}$, allylic chlorides ${ }^{9}$ or 1 -bromo-1fluoroalkane ${ }^{10}$ and unactivated racemic alkyl halides such as $\beta$ - or $\gamma$-ether, amide or sulfonyl-substituted alkyl bromides ${ }^{11,12}$, and $\alpha$ haloboronates ${ }^{13}$ were effectively employed as the coupling partners, while the choice of nucleophiles was originally mainly focused on alkyl zinc halides. Only recently, the nickel-catalyzed asymmetric couplings of racemic alkyl halides were successfully extended to other nucleophiles such as alkyl-9-BBN, aryl Grignard reagents, aryl zinc halides, aryl/vinyl silicates vinyl/alkynyl indium/zirconium/ aluminum reagents (Fig. 1a) ${ }^{6,14-19}$.

Organoboron reagents are one of the most widely studied and applied reagents that allows for the efficient construction of carbon-carbon and carbon-heteroatom bonds ${ }^{20-22}$. Nonasymmetric couplings of secondary alkyl bromides with aryl boronic acids under nickel catalysis have been reported in early $2004^{23}$. Yet, mainly due to the slow transmetalation step of the aryl boronic acid to the active nickel intermediate, theses reactions typically required $60^{\circ} \mathrm{C}$ to occur to full conversion. To facilitate the transmetalation step, Fu and co-workers ${ }^{15}$ turned to alkyl-9-BBN and found that the reaction could be conducted at 5 ${ }^{\circ} \mathrm{C}$-room temperature to ensure high enantioselectivity. Nevertheless, alkyl boranes are generally air and moisture sensitive and should be prepared in situ by hydroboration of alkene before use, which hampered their widespread applications.

In 2017, we discovered that the transmetalation step in nickelcatalyzed asymmetric Suzuki-Miyaura coupling of $\mathrm{CF}_{3} \mathrm{O}$ substituted secondary benzylic bromide was much faster when easily available, air-insensitive lithium organoboronate instead of

a

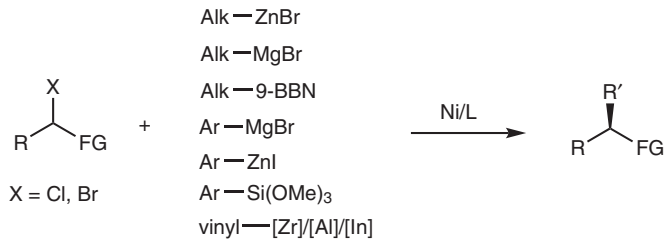

b

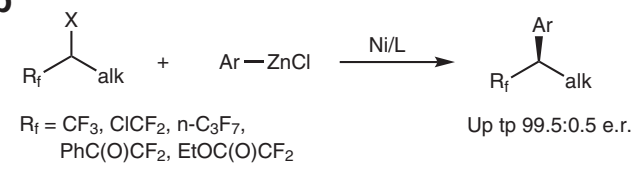

C

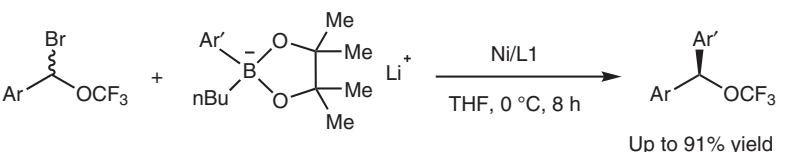
Up to $91 \%$ yield

d

$$
\begin{aligned}
& \mathrm{Ar}_{\mathrm{K}_{\mathrm{f}}}^{\mathrm{Br}}+\mathrm{Li}^{+}{ }_{\left[\mathrm{Ar}{ }_{2}{ }_{2} \mathrm{ZnBr}\right]}^{-} \stackrel{[\mathrm{Ni}] / \mathrm{L}_{2}}{\longrightarrow} \\
& \mathrm{R}_{\mathrm{f}}=\mathrm{CF}_{3}, \mathrm{CF}_{2} \mathrm{H}, \mathrm{CH}_{2} \mathrm{~F} \quad \text { Up to } 98: 2 \text { e.r. }
\end{aligned}
$$

Fig. $1 \mathrm{Ni}$-catalyzed asymmetric cross-coupling of racemic secondary alkyl halides. a State-of-the-art. b Coupling of fluoroalkylated secondary alkyl bromides with Aryl zinc chloride. c Coupling with lithium borates. d Coupling with in situ generated zincate (this work) aryl boronic acid was used as the nucleophile ${ }^{24}$. In this case, the reaction occurred smoothly at $0{ }^{\circ} \mathrm{C}$ to give the coupled product with a $\mathrm{CF}_{3} \mathrm{O}$-stustituted stereogenic center with excellent enantioselectivity (Fig. 1c). Inspired by this discovery and considering the fact that fluoroalkyl groups, including trifluoromethyl $\left(\mathrm{CF}_{3^{-}}\right)$, difluoromethyl $\left(\mathrm{HCF}_{2^{-}}\right)$and monofluoromethyl $\left(\mathrm{CH}_{2} \mathrm{~F}-\right)$ group are important structural motifs in refining the lead compound's selectivity and pharmacokinetics for new drug discovery ${ }^{25-28}$, we envisaged that the same strategy might work if a fluoroalkylated secondary benzylic bromide was allowed to react with lithium organoboronate. One main problem for the transition-metalcatalyzed coupling reactions of fluoroalkylated secondary benzylic bromides is the fluoride elimination from the fluoroalkylated secondary benzylic metal species if the subsequent transmetalation step is too slow ${ }^{29,30}$. The key for the success of such a coupling reaction, therefore, is to accelerate the transmetalation step. Herein, we report the use of lithium aryl zincate $\left[\mathrm{Ph}_{2} \mathrm{ZnBr}\right]$ $\mathrm{Li}$ facilitates the transmetalation step of the nickel-catalyzed cross-coupling reaction. Consequently, a nickel-catalyzed highly enantioselective coupling reaction for the construction of the optically active fluoroalkylated benzhydryl derivatives from easily available racemic a-bromobenzyl trifluoro-/difluoro-/monofluoromethanes and lithium organoboronates was developed (Fig. 1d).

\section{Results}

Screening of reaction conditions. Initially, we tried the reaction of racemic trifluoromethylated benzylic bromide $\mathbf{1 a}$ and lithium organoboronate $2 \mathbf{a}$ as a model reaction to optimize the reaction conditions. Surprisingly, the reaction did not take place at all when it was conducted in tetrahedrofuran (THF) at $0{ }^{\circ} \mathrm{C}$ for $8.0 \mathrm{~h}$ using a combination of $20 \mathrm{~mol} \% \mathrm{NiBr}_{2} \cdot \mathrm{DME}$ and $25 \mathrm{~mol} \% \mathrm{~L} 1 \mathrm{as}$ the catalyst, which is the condition for the construction of trifluoromethoxylated stereogenic center (Fig. 2a). Notably, when 1.0 equivalent of $\mathrm{ZnBr}_{2}$ was used as additive, the reaction occurred after $8 \mathrm{~h}$ at $0{ }^{\circ} \mathrm{C}$ to afford the coupled product in $65 \%$ yield with $85: 15$ e.r. (Fig. 2a). As a comparison, we studied the reaction of other nucleophiles such as Grignard reagent $\mathrm{PhMgBr}$ or PhZnBr. As summarized in (Fig. 2b, c), reaction of substrate 1a with $\mathrm{PhMgBr}$, under the identical conditions, mainly afforded the undesired defluorinated side product in 51\% yield, while the reaction of substrate 1a with $\mathrm{PhZnBr}$ were slow and the formation of the coupled product was not observed.

A quick further survey of the reaction conditions disclosed that a combination of $\mathrm{NiBr}_{2} \bullet \mathrm{DME}$ with ligand $\mathrm{L} 2$ was the most efficient catalyst and the desired product 3a was obtained in $62 \%$ yield with $95.5: 4.5$ e.r. along with the undesired defluorinated side product 3a' in $5 \%$ yield when the reaction was conduct at $-15^{\circ} \mathrm{C}$ for $12 \mathrm{~h}$ (Table 1, entry 1). Switching the additive to $\mathrm{ZnCl}_{2}$ gave slightly inferior results, while using $\mathrm{MgBr}_{2}$ as additive was not effective at all (Table 1, entries 2-3). Further studied showed that reactions in DME or diglyme occurred in moderate yields and good enantioselectivity, while reactions in other solvents such as THF, DMA, or DMF were less effective and reaction in toluene was completely shut down (Table 1, entries 4-8). Notably, using a combination of DME/diglyme $(v / v=1 / 1)$ as the solvent gave slightly improved yield and enantioselectivity (Table 1, entry 9). The amount of $\mathrm{ZnBr}_{2}$ was also important for the reaction. While the reaction with 2.0 equivalents of $\mathrm{ZnBr}_{2}$ gave comparative yield and enantioselectivity, reaction conducted with 0.5 equivalent of $\mathrm{ZnBr}_{2}$ occurred in much lower yield although the enantioselectivity was high (Table 1, entries 11-12). We next studied the effect of different nickel precursors and ligands. It was found that reaction using different nickel precursors such as $\mathrm{NiCl}_{2} \bullet \mathrm{DME}$ or $\mathrm{Ni}(\mathrm{OAc})_{2}$ had little effect on the efficiency of the reaction. Yet, the 
a<smiles>Fc1ccc(C(Br)C(F)(F)F)cc1</smiles>

$1 \mathbf{a}\left(\mathrm{E}=\mathrm{CO}_{2} \mathrm{Me}\right)$

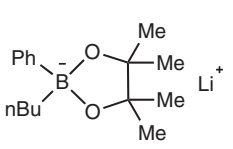

2a (3.0 equiv.)

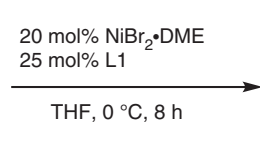

$\mathrm{ZnBr}_{2}$ (1.0 equiv.): $65 \%$ yield

b<smiles>Fc1ccc(C(Br)C(F)(F)F)cc1</smiles>

1a $\left(\mathrm{E}=\mathrm{CO}_{2} \mathrm{Me}\right)$<smiles>[Mg][Mg]Br</smiles>

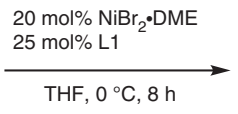

$\mathrm{THF}, 0{ }^{\circ} \mathrm{C}, 8 \mathrm{~h}$

C

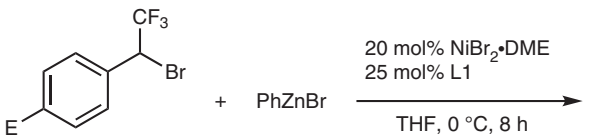

1a $\left(\mathrm{E}=\mathrm{CO}_{2} \mathrm{Me}\right)$<smiles>CC(F)(F)c1ccc(F)cc1</smiles>

$0 \%$ yield<smiles>Fc1ccc(C(c2ccccc2)C(F)(F)F)cc1</smiles>

$0 \%$ yield<smiles>Fc1ccc(C(c2ccccc2)C(F)(F)F)cc1</smiles>
$85: 15$ e.r.

$51 \%$ yield<smiles>FC(F)=Cc1ccc(F)cc1</smiles>

$0 \%$ yield

Fig. 2 Ni-catalyzed asymmetric cross-coupling reaction with different nucleophiles. a Coupling with lithium phenyl boronate. b Coupling with Grignard reagent. c Coupling with aryl zinc halide

\section{Table 1 Optimization of the reaction conditions}

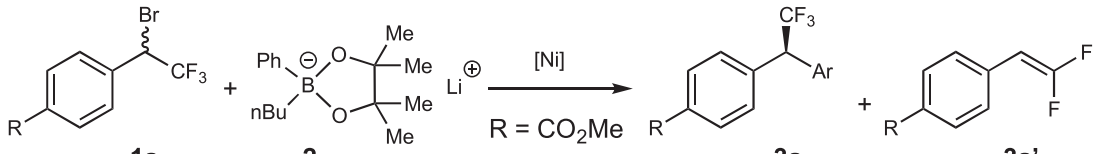

$1 a$

2

$3 a$<smiles>Cc1cccnc1C1=N[C@H]2c3ccccc3C[C@H]2O1</smiles><smiles>ClC[C@H]1COC(c2ncc(Cl)cc2Br)=N1</smiles><smiles>COc1ccc(C2=N[C@@H](CC3CCCCC3)CO2)nc1</smiles>

L3<smiles>FC(F)(F)c1ccc(C2=N[C@@H](CCl)CO2)nc1</smiles><smiles>CC(C)[C@H]1COC(c2cccc(C3=N[C@H](C(C)C)CO3)n2)=N1</smiles><smiles>CC(C)[C@H]1COC(C(C)(C)C2=N[C@H](C(C)C)CO2)=N1</smiles>

L6

\begin{tabular}{|c|c|c|c|c|c|c|c|c|}
\hline \multirow[t]{2}{*}{ Entry } & \multirow[t]{2}{*}[\mathrm{Ni}]{} & \multirow[t]{2}{*}{ Ligand } & \multirow[t]{2}{*}{ Additive } & \multirow[t]{2}{*}{ Solvent } & \multirow[t]{2}{*}{ Temp $\left({ }^{\circ} \mathrm{C}\right)$} & \multicolumn{2}{|c|}{ Yield $(\%)^{a}$} & \multirow[t]{2}{*}{ e.r. ${ }^{b}$} \\
\hline & & & & & & 3 & $3^{\prime}$ & \\
\hline 1 & $\mathrm{NiBr}_{2} \bullet \mathrm{DME}$ & $\mathrm{L} 2$ & $\mathrm{ZnBr}_{2}$ & DME & -15 & 62 & 5 & $95.5: 4.5$ \\
\hline 2 & $\mathrm{NiBr}_{2} \bullet \mathrm{DME}$ & L2 & $\mathrm{ZnCl}_{2}$ & DME & -15 & 54 & 8 & $95: 5$ \\
\hline 3 & $\mathrm{NiBr}_{2} \bullet \mathrm{DME}$ & $\mathrm{L} 2$ & $\mathrm{MgBr}_{2}$ & DME & -15 & 0 & 0 & - \\
\hline 4 & $\mathrm{NiBr}_{2} \bullet \mathrm{DME}$ & L2 & $\mathrm{ZnBr}_{2}$ & Diglyme & -15 & 78 & 0 & $95: 5$ \\
\hline 5 & $\mathrm{NiBr}_{2} \bullet \mathrm{DME}$ & $\mathrm{L} 2$ & $\mathrm{ZnBr}_{2}$ & THF & -15 & 50 & 28 & $94.5: 5.5$ \\
\hline 6 & $\mathrm{NiBr}_{2} \bullet \mathrm{DME}$ & L2 & $\mathrm{ZnBr}_{2}$ & Toluene & -15 & - & - & - \\
\hline 7 & $\mathrm{NiBr}_{2} \bullet \mathrm{DME}$ & $\mathrm{L} 2$ & $\mathrm{ZnBr}_{2}$ & DMA & -15 & 47 & 6 & $93: 7$ \\
\hline 8 & $\mathrm{NiBr}_{2} \bullet \mathrm{DME}$ & $\mathrm{L} 2$ & $\mathrm{ZnBr}_{2}$ & DMF & -15 & 30 & 6 & $93: 7$ \\
\hline 9 & $\mathrm{NiBr}_{2} \bullet \mathrm{DME}$ & $\mathrm{L} 2$ & $\mathrm{ZnBr}_{2}$ & DME/diglyme & -15 & 80 & 0 & $96: 4$ \\
\hline 10 & $\mathrm{NiBr}_{2} \bullet \mathrm{DME}$ & $\mathrm{L} 2$ & $\mathrm{ZnBr}_{2}$ & $\mathrm{DME} /$ diglyme & $\mathrm{rt}$ & 75 & 15 & $94: 6$ \\
\hline $11^{c}$ & $\mathrm{NiBr}_{2} \cdot \mathrm{DME}$ & $\mathrm{L} 2$ & $\mathrm{ZnBr}_{2}$ & $\mathrm{DME} /$ diglyme & -15 & 32 & 5 & $95.5: 4.5$ \\
\hline $12^{d}$ & $\mathrm{NiBr}_{2} \bullet \mathrm{DME}$ & $\mathrm{L} 2$ & $\mathrm{ZnBr}_{2}$ & DME/diglyme & -15 & 75 & 2 & 95.5:4.5 \\
\hline 13 & $\mathrm{NiCl}_{2} \bullet \mathrm{DME}$ & L2 & $\mathrm{ZnBr}_{2}$ & DME/diglyme & -15 & 70 & 9 & $95.5: 4.5$ \\
\hline 14 & $\mathrm{Ni}(\mathrm{OAc})_{2}$ & L2 & $\mathrm{ZnBr}_{2}$ & DME/diglyme & -15 & 71 & 6 & $96: 4$ \\
\hline 15 & $\mathrm{NiBr}_{2} \bullet \mathrm{DME}$ & L1 & $\mathrm{ZnBr}_{2}$ & DME/diglyme & -15 & 70 & 15 & $88: 12$ \\
\hline 16 & $\mathrm{NiBr}_{2} \bullet \mathrm{DME}$ & L3 & $\mathrm{ZnBr}_{2}$ & $\mathrm{DME} /$ diglyme & -15 & 81 & 0 & $94: 6$ \\
\hline 17 & $\mathrm{NiBr}_{2} \bullet \mathrm{DME}$ & L4 & $\mathrm{ZnBr}_{2}$ & DME/diglyme & -15 & 30 & 50 & $90: 10$ \\
\hline 18 & $\mathrm{NiBr}_{2} \bullet \mathrm{DME}$ & L5 & $\mathrm{ZnBr}_{2}^{2}$ & DME/diglyme & -15 & 0 & 0 & - \\
\hline 19 & $\mathrm{NiBr}_{2} \bullet \mathrm{DME}$ & L6 & $\mathrm{ZnBr}_{2}$ & $\mathrm{DME} /$ diglyme & -15 & 24 & 0 & $58: 42$ \\
\hline $20^{\mathrm{e}}$ & - & $\mathrm{L} 2$ & $\mathrm{ZnBr}_{2}$ & $\mathrm{DME} /$ diglyme & -15 & 0 & 0 & - \\
\hline
\end{tabular}

Unless otherwise noted, all reactions were carried out with compound $\mathbf{1 a}(0.1 \mathrm{mmol}), \mathbf{2}(0.3 \mathrm{mmol}), \mathrm{NiBr}_{2} \bullet \mathrm{DME}(20 \mathrm{~mol} \%)$, ligand (25 mol\%) under conditions indicated in the scheme

aYields were determined by ${ }^{19} \mathrm{~F}$ NMR spectroscopy with trifluorotoluene as an internal standard

betemined by chiral HPLC analysis

c 0.5 equiv. of $\mathrm{ZnBr}_{2}$ was used

2.0 equiv. of $\mathrm{ZnBr}_{2}$ was used

${ }^{\mathrm{N}} \mathrm{NiBr}_{2} \bullet \mathrm{DME}(10 \mathrm{~mol} \%)$, ligand L2 (12.5 mol\%)

$\mathrm{NiBr}_{2} \bullet \mathrm{DME}(10 \mathrm{~mol} \%)$, ligand $\mathrm{L} 2(12.5 \mathrm{~mol} \%)$
$\mathrm{gNiBr}_{2} \bullet \mathrm{DME}(5 \mathrm{~mol} \%)$, ligand L2 (6.25 mol\%) 


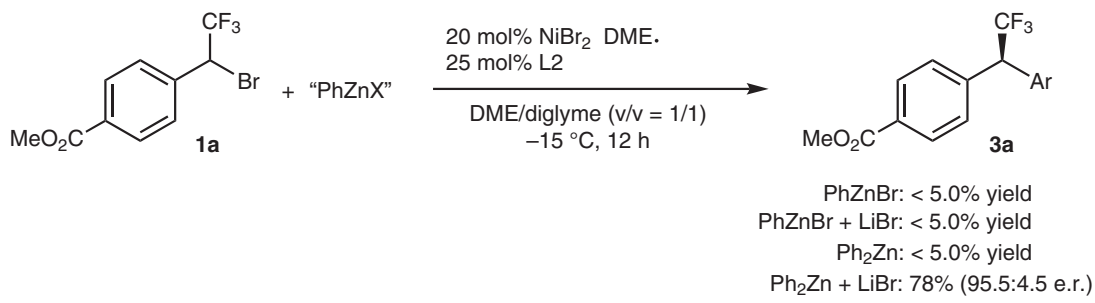

Fig. 3 Control experiments. The effects of different nucleophiles

choice of the ligand plays a key role in delivering the good yields and high enantioselectivity. Pyridine-oxazoline ligand with either an electron-donating group (-OMe) or an electron-withdrawing group $\left(-\mathrm{CF}_{3}\right)$ at 5 -position, as well as a methyl group at 3-position of the pyridyl moiety were less effective (Table 1, entries 15-17). Likewise, two commonly used dinitrogen ligands for nickelcatalyzed asymmetric coupling reaction were also ineffective under these conditions (Table 1, entries 18-19). Control experiment showed that reaction in the absence of nickel catalyst did not occur at all (Table 1, entry 20). Furthermore, efforts to decreasing the catalyst loadings disclosed that the amount of side products increased to $9-15 \%$ when a combination of $10 \mathrm{~mol} \%$ $\mathrm{NiBr}_{2} \bullet \mathrm{DME}$ and $12.5 \mathrm{~mol} \% \mathrm{~L} 2$ or $5.0 \mathrm{~mol} \% \mathrm{NiBr}_{2} \bullet \mathrm{DME}$ and 6.25 mol\% L2 was used (Table 1, entries 21-22).

Mechanistic investigation. During the optimization of the reaction conditions, it was found that addition of 1.0 equivalent of $\mathrm{ZnBr}_{2}$ dramatically accelerated the reaction rate. Presumptively, mixing lithium aryl boronate with $\mathrm{ZnBr}_{2}$ might generate several different arylated zinc species that could accelerate the transmetalation step and the overall catalytic reaction. To probe which arylated zinc species was involved in the reaction, we did several control experiments (Fig. 3). First, reaction of compound 1a with 3.0 equivalents of $\mathrm{PhZnBr}$ in the presence/absence of 3.0 equivalents of $\mathrm{LiBr}$ occurred under standard conditions in less than $5 \%$ yield of the coupled product. Likewise, reaction of compound 1a with 3.0 equivalents of $\mathrm{Ph}_{2} \mathrm{Zn}$, again, gave the desired product in less than $5 \%$ yield. These results clearly excluded the possibility of the involvement of $\mathrm{PhZnBr}$ and $\mathrm{Ph}_{2} \mathrm{Zn}$ in the current reaction. Interestingly, addition of 3.0 equivalent of $\mathrm{LiBr}$ to the reaction of compound $1 \mathrm{a}$ with $\mathrm{Ph}_{2} \mathrm{Zn}$ led to full conversion of the starting material and gave the coupled compound $3 \mathbf{a}$ in $78 \%$ yield with 95.5:4.5 e.r. These experimental results suggest that an anionic zincate $\left[\mathrm{Ph}_{2} \mathrm{ZnBr}\right]^{-}$might be involved in the reaction, consistent with the observation from Ingleson and co-workers ${ }^{31}$ that mixing 2.0 equivalents of lithium aryl boronate with $\mathrm{ZnBr}_{2}$ at room temperature generated an anionic $\left[\mathrm{Ph}_{\mathrm{x}} \mathrm{ZnBr}_{\mathrm{y}}\right]^{-}(x+y=3)$.

To gain more support about the formation of lithium zincate from lithium aryl boronate with $\mathrm{ZnBr}_{2}$, we studied and compared the ${ }^{13} \mathrm{C}$ nuclear magnetic resonance (NMR) spectra of the species generated from mixing lithium aryl boronate with $\mathrm{ZnBr}_{2}$ and $\mathrm{Ph}_{2} \mathrm{Zn}$ with LiBr. As shown in Fig. 4, mixing equimolar amount of $\mathrm{Ph}_{2} \mathrm{Zn}$ with $\mathrm{LiBr}$ at room temperature in THF-d8 for $0.5 \mathrm{~h}$ cleanly generated $\left[\mathrm{Ph}_{2} \mathrm{ZnBr}\right] \mathrm{Li}$, as evidence by a peak with a chemical shift at $161.0 \mathrm{ppm}$ in ${ }^{13} \mathrm{C} \mathrm{NMR}$ spectrum, which corresponds to the ipso-carbon of the phenyl group in $\left[\mathrm{Ph}_{2} \mathrm{ZnBr}\right] \mathrm{Li}$. Likewise, the same species was formed after $0.5 \mathrm{~h}$ at room temperature for the reaction of 3.0 equivalvents of lithium phenyl boronate $\mathbf{2 a}$ with $\mathrm{ZnBr}_{2}$. These results suggest an anionic arylated zincate $\left[\mathrm{Ph}_{2} \mathrm{ZnBr}\right] \mathrm{Li}$ could facilitate the transmetalation step, and consequently, accelerates the overall catalytic reaction. However, we could not exclude an alternative pathway in which $\mathrm{ZnBr}_{2}$ may abstract a bromide from
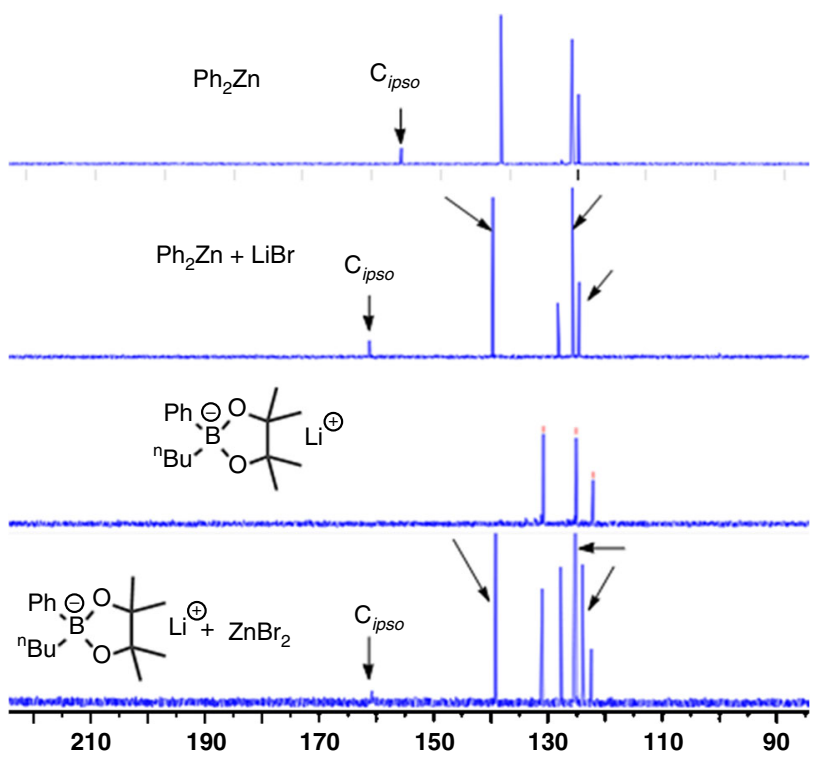

Fig. $4 \mathrm{NMR}$ detection of intermediates. ${ }^{13} \mathrm{C} N M R$ spectra of $\mathrm{Ph}_{2} \mathrm{Zn}, \mathrm{Ph}_{2} \mathrm{Zn}$ $+\mathrm{LiBr}, \mathbf{2 a}$ and $\mathbf{2 a}+\mathrm{ZnBr}_{2}$ in THF-d8

nickel benzylic bromide complex to generate a cationic $\eta^{3}$-benzyl nickel species $^{32}$ that could more rapidly participate in a transmetalation reaction with lithium organoboronate $\mathbf{2 a}$.

Substrate scope investigation. Having identified the optimized conditions and the likelihood role of $\mathrm{ZnBr}_{2}$, we next investigated the generality of the nickel-catalyzed coupling reaction for the preparation of enantio-enriched benzhydryl trifluoromethane derivatives. As summarized in Fig. 5, in general, trifluoromethylated benzylic bromides (1a-e) with electron-withdrawing substituted groups such as ester, cyano, nitro, trifluoromethyl or trifluoromethoxy group reacted smoothly with lithium phenyl boronates $\mathbf{2 a - f}$ to afford the coupled products in moderate to good yields and enantioselectivities (Figs. 5 and $3 \mathbf{a}-\mathbf{h}, \mathbf{j}-\mathbf{m})$. For example, reactions of both a-bromo-4nitrobenzyl trifluoromethane and a-bromo-3-trifluoromethyl benzyl trifluoromethane with lithium phenyl boronate 2a gave the corresponding products $\mathbf{3 k}$ and $\mathbf{3} \mathbf{~ m}$ in $53 \%$ and $75 \%$ yields with excellent enantioselectivities 96:4 and 97:3 e.r., respectively, (Figs. 5 and 3k, m). Notably, trifluoromethylated benzylic bromides with a halogen group such as chloride, bromide, and fluorine were compatible and reacted with lithium phenyl boronates $\mathbf{2 a}$ to give the corresponding products $3 \mathbf{n}-\mathbf{p}$ in $65 \%, 68 \%$, and $52 \%$ yields, with $96: 4,95: 5$ and $96: 4$ e.r., respectively (Figs. 5, 3n-p). Furthermore, a-bromobenzyl trifluoromethyl with para-, meta-, and ortho-substituents are all compatible coupling partners, affording the desired products in moderate to good yields and enantioselectivities. For example, both a-bromo3,5-dibromide benzyl trifluoromethane and a-bromo-2-fluorine-4cyano benzyl trifluoromethane reacted to afford compounds $3 \mathbf{v}, 3 \mathbf{y}$ in 


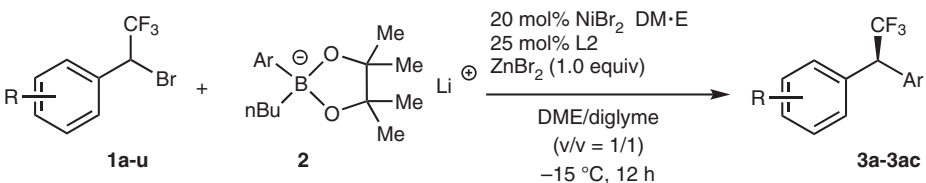<smiles>COC(=O)c1ccc([C@@H](c2cccc([C@@H](c3ccc(C(=O)OC)cc3)c3cccc(C(=O)OC)c3)c2)c2cccc(N3CCOCC3)c2)cc1</smiles><smiles>COC(=O)c1ccc(C(c2ccc(C(=O)OC)cc2)c2ccc(C(=O)OC(C)([18OH])[18OH])cc2)cc1</smiles><smiles>N#Cc1ccc([C@H](c2ccccc2)C(F)(F)F)cc1</smiles>
92:8 e.r.<smiles>FC(F)(F)Oc1ccc([C@@H](c2ccccc2)C(F)(F)F)cc1</smiles><smiles>FC(F)(F)c1cccc(C(c2ccccc2)C(F)(F)F)c1</smiles>

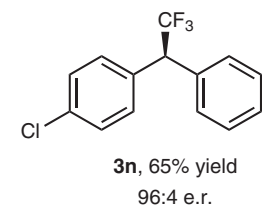<smiles>FC(F)(F)[C@@H](c1ccccc1)c1ccc(Br)cc1</smiles>

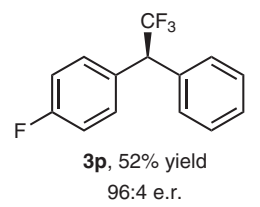<smiles>FC(F)(F)[C@H](c1ccccc1)c1ccc(-c2ccccc2)cc1</smiles><smiles>CC(=O)Oc1ccc([C@@H](c2ccccc2)C(F)(F)F)cc1</smiles><smiles>CC(=O)c1cccc([C@H](c2ccccc2)C(F)(F)F)c1</smiles><smiles>O=[N+]([O-])c1cccc(C(c2ccccc2)C(F)(F)F)c1</smiles><smiles>FC(F)(F)[C@H](c1ccccc1)c1cccc(Cl)c1</smiles><smiles>FC(F)(F)[C@H](c1ccccc1)c1cc(Br)cc(Br)c1</smiles><smiles>N#Cc1cc(F)cc([C@@H](c2ccccc2)C(F)(F)F)c1</smiles><smiles>O=[N+]([O-])c1cc([C@H](c2ccccc2)C(F)(F)F)ccc1F</smiles><smiles>N#Cc1ccc([C@@H](c2ccccc2)C(F)(F)F)c(F)c1</smiles><smiles>CC(=O)c1ccc(C(c2ccccc2)C(F)(F)F)cc1F</smiles><smiles>FC(F)(F)[C@H](c1ccccc1)c1ccc2ccccc2c1</smiles><smiles>CC(C)(C)c1ccc([C@H](c2ccccc2)C(F)(F)F)cc1</smiles><smiles>COc1ccc(C(c2ccccc2)C(F)(C(F)(F)F)C(F)(F)F)cc1</smiles>

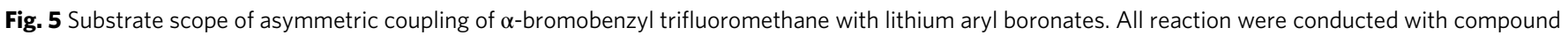
$1(0.3 \mathrm{mmol})$, phenylboronic pinacol ester 2 (0.9 mmol), $\mathrm{NiBr}_{2} \bullet \mathrm{DME}(20 \mathrm{~mol} \%)$, ligand $\mathrm{L} 2(25 \mathrm{~mol} \%)$ and $\mathrm{ZnBr} 2(0.3 \mathrm{mmol})$ in $\mathrm{DME} / \mathrm{diglyme}_{2}(\mathrm{v} / \mathrm{v}=1 / 1)$ at $-15^{\circ} \mathrm{C}$ for $12 \mathrm{~h}$. Isolated yields and e.r. was determined by chiral HPLC analysis

$58 \%$ and $71 \%$ yield with $96: 4$ and $98: 2$ e.r., respectively (Figs. 5, 3v, y). Nevertheless, trifluoromethylated benzylic bromides with electrondonating groups occurred in much less yields and moderate enantioselectivities (Figs. 5, 3ab-ac). In these cases, the formations of two side products including the homocoupling side products and the defluorinated side products were observed. Next, we investigated the scope of lithium aryl boronates. It was found that reactions of lithium aryl boronates with meta-substituted aryl groups occured in moderate to good yields and enantiolectivities (Figs. 5, 3b-e), while reactions of para-methyl or fluoride substituted lithium aryl boronates occurred to generate the corresponding products in moderate yields and enantioselectivities (Figs. 5, 3g, h). However, the formation of the desired coupling product was not observed when lithium aryl boronates with ortho-methyl group (2i) was subjected to the reaction conditions (Scheme 2, 3i). Previously reported method for the preparation of enantio-enriched benzhydryl trifluoromethane derivatives typically required to use optically secondary $\alpha$-(trifluoromethyl)benzyl tosylates to react with various aryl boronic acids in the presence of a palladium catalyst ${ }^{19,29,33-36}$, while $\mathrm{Fu}$ and coworker ${ }^{37}$ reported a highly enantioselective nickel-catalyzed coupling of fluoroalkylated secondary alkyl bromide with aryl zinc chlorides (Fig. 1c). Thus, the current method provided an alternative, more efficient method to access this family of compounds.

Encouraged by the high enantioselectivity in nickel-catalyzed coupling of $\alpha$-bromobenzyl trifluoromethane with lithium aryl boronates, we next tried to extend this reaction to other fluoroalkyl-substituted benzyl bromides. After a quick screen of the reaction conditions, it was found that when a more sterically 

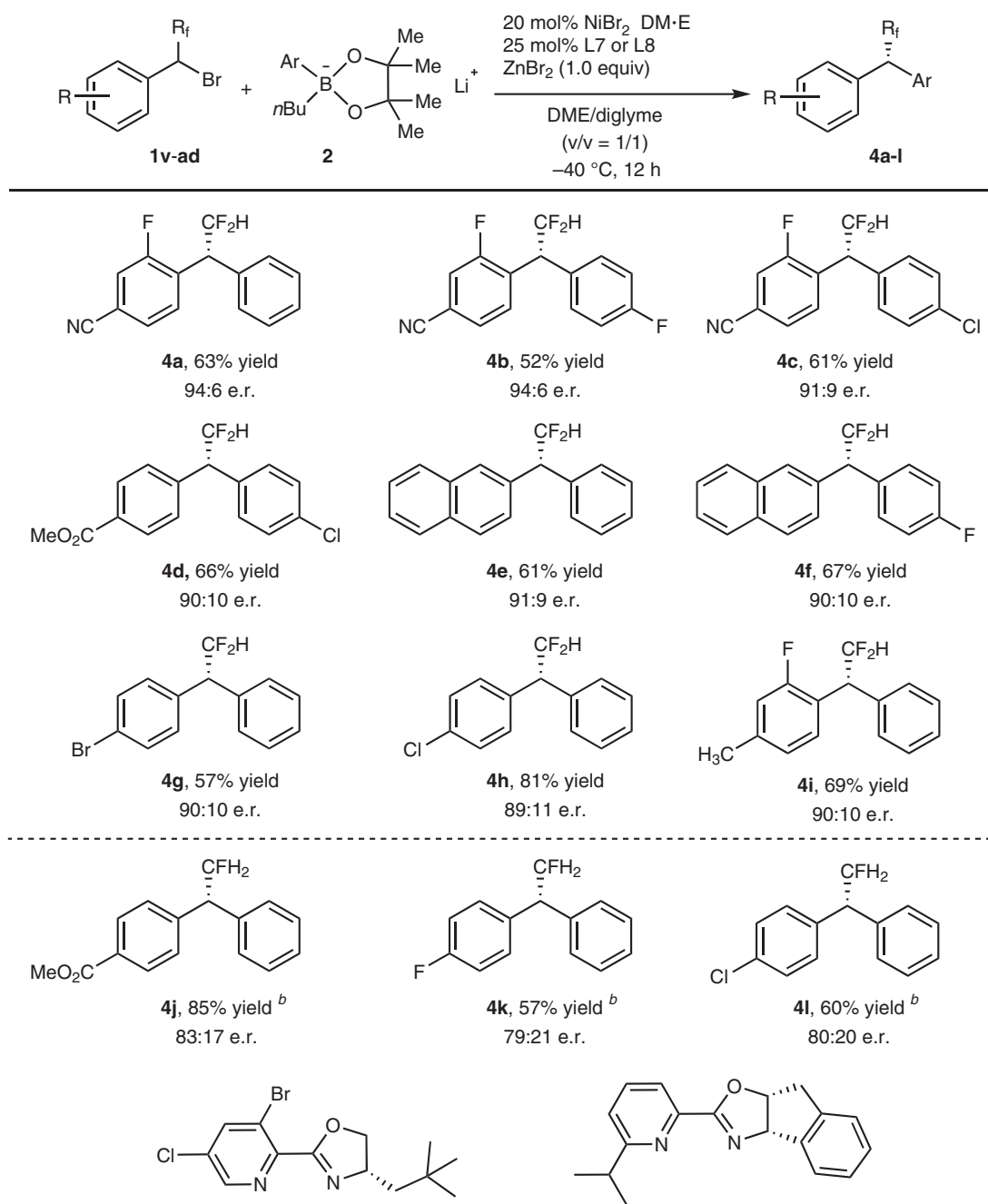

L7

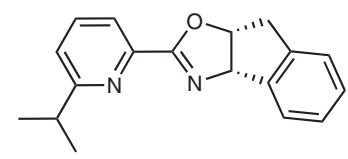

L8

Fig. 6 Substrate scope for reactions with $\alpha$-bromobenzyl di-/mono-fluoromethane. All reaction were conducted with compound 1 ( $0.3 \mathrm{mmol}$ ), phenylboronic pinacol ester $2(0.9 \mathrm{mmol}), \mathrm{NiBr}_{2} \bullet \mathrm{DME}(20 \mathrm{~mol} \%)$, ligand $\mathrm{L} 7$ or L8 (25 mol\%) and $\mathrm{ZnBr}_{2}(0.3 \mathrm{mmol})$ in DME/diglyme $(v / v=1 / 1)$ at -10 or $-40^{\circ} \mathrm{C}$ for $12 \mathrm{~h}$. Isolated yields and e.r. was determined by chiral HPLC analysis

hindered ligand $\mathbf{L 7}$ was used as the ligand and the reaction temperature was decreased to $-40{ }^{\circ} \mathrm{C}$, good enantioselectivities could be achieved (Fig. 6). For example, reactions of 4-(1-bromo2,2-difluoroethyl)-3-fluorobenzonitrile with lithium phenyl boronate $\mathbf{2 a}$ and lithium 4-fluorophenyl boronate $\mathbf{2} \mathbf{h}$ occurred smoothly after $12 \mathrm{~h}$ to afford the corresponding products in 94:6 e.r. (Figs. 6 and 4a, b). Since few methods for the construction of difluoromethyl-substituted stereogenic carbon center have been reported previously ${ }^{38,39}$, the current method represents an attractive approach for the preparation of optically active difluoromethylated benzhydryl derivatives.

On the other hand, reaction of monofluoromethylated substrates were much more challenging. After carefully screening of the combination of nickel salts and ligands, it was found that using a combination of $\mathrm{NiBr}_{2} \bullet \mathrm{DME}$ with ligand $\mathbf{L 8}$ could catalyze the reactions of 4-(1-bromo-2-fluoroethyl)arenes with lithium phenyl boronate $\mathbf{2 a}$ to give the corresponding coupled products $\mathbf{4 j - 1}$ after $12 \mathrm{~h}$ at $-10^{\circ} \mathrm{C}$ in moderate enantioselectivities (79:21 $\sim$ 83:17 e.r.).

Synthetic application. To showcase the applicability of the nickel-catalyzed asymmetric coupling reaction of racemic trifluoromethylated benzylic bromide with lithium organoboronate, we applied this protocol for the synthesis of trifluoromethylated mimic of an inhibitor for the histone lysine methyltransferase enhancer of Zeste Homolog $2(\mathrm{EZH} 2)^{40}$. As shown in Fig. 7, compound 5 was generated in 55\% overall yield with 94:6 e.r. via a four-step transformation from easily available a-bromo-4-tert-butoxycarbylbenzyl trifluoromethane.

Owing to the slightly acidic proton in the difluoromethyl group, which allows it to act as a lipophilic hydrogen-bond donor, the difluoromethyl group $\left(\mathrm{CHF}_{2}\right)$ was generally considered as a bioisostere for a hydroxy goup $(-\mathrm{OH})^{41}$. Replacement of a hydroxy group of a drug molecule with a difluoromethyl group may result in a Me-too or Me-better drug molecule. Consequently, a difluoromethylated compound $\mathbf{6}$, which is a mimic of histamine $\mathrm{H} 3$ receptor ${ }^{42}$, was synthesized in $71 \%$ overall yield and 90:10 e.r. after four steps.

\section{Discussion}

Inspired by the mechanistic studies disclosed that a highly reactive zincate $\left[\mathrm{Ph}_{2} \mathrm{ZnBr}\right] \mathrm{Li}$ would facilitate the transmetalation step of the nickel-catalyzed cross-coupling reaction, we successfully developed a highly enantioselective nickel-catalyzed coupling of 


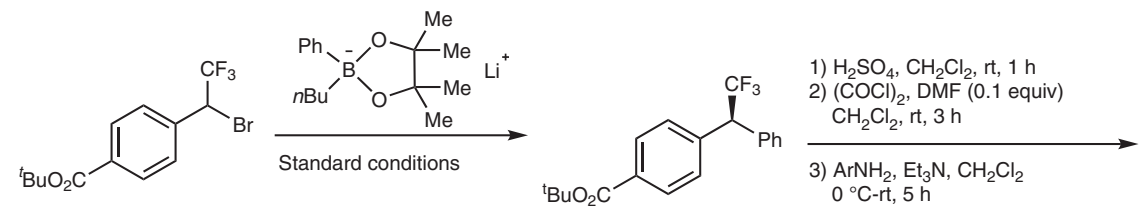

5a, $68 \%$ yield, $94.5: 5.5$ e.r.<smiles>Cc1cc(C)c(CNC(=O)c2ccc([C@H](c3ccccc3)C(F)(F)F)cc2)c(O)n1</smiles>

$81 \%$ yield, $94: 6$ e.r.

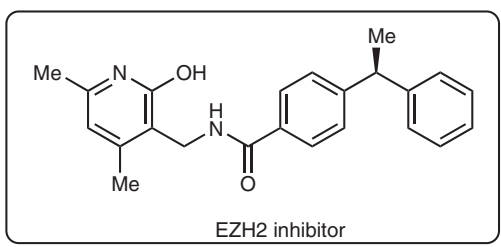<smiles>CCO[B-]1(c2ccccc2)OC(C)(C)C(C)(C)O1</smiles>

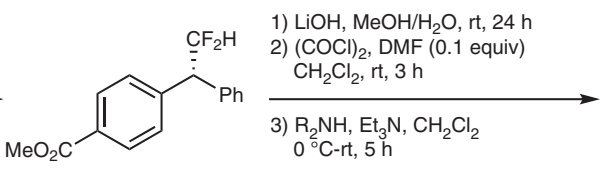

6a, $76 \%$ yield, $91: 9$ e.r.
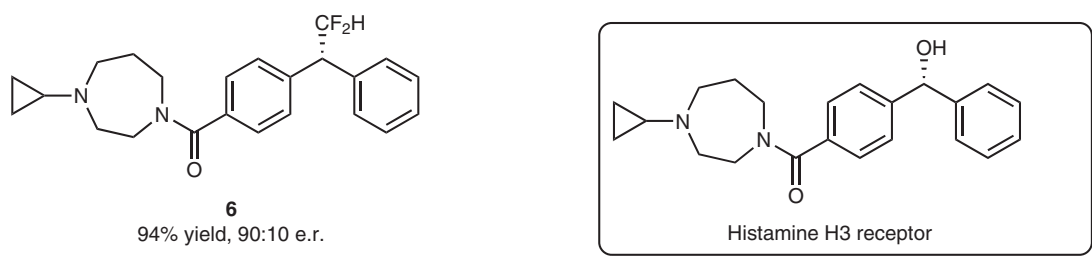

Fig. 7 Synthetic applications. Application in the preparation of fluoroalkylated derivatives of drug candidates

easily available $\alpha$-bromobenzyl fluooalkanes with a variety of lithium aryl boronates in the presence of stochiometric amount of $\mathrm{ZnBr}_{2}$. Thus, the protocol may serve as a versatile, efficient, and convenient approach for the rapid access of chiral benzhydryl fluoroalkane derivatives. The application of the high-reactive lithium aryl zincate $\left[\mathrm{Ar}_{2} \mathrm{ZnBr}\right] \mathrm{Li}$ in other transition-metalcatalyzed cross-coupling reactions are undergoing currently in our laboratory.

\section{Methods}

Coupling of trifluoromethylated secondary benzyl bromides. In a glove box, phenylpinacolboronate ester $(5.1 \mathrm{~g}, 25 \mathrm{mmol})$ was weighted into a $100 \mathrm{~mL}$ Schlenk tube, and $40 \mathrm{~mL}$ of anhydrous THF was added. The mixture was taken out from the glove box and cooled at $-20^{\circ} \mathrm{C}$. $n$ - BuLi ( $25 \mathrm{mmol}, 10 \mathrm{~mL}, 2.5 \mathrm{M}$ in Hexanes) was added. The mixture was stirred at $-20^{\circ} \mathrm{C}$ for $2 \mathrm{~h}$. Then the Schlenk tube was taken into the glove box, the solvents were removed under vacuum to give lithium phenyl pinacol boronate.

In an argon-filled glove box, lithium organoborate $(371 \mathrm{mg}, 0.900 \mathrm{mmol}, 3.00$ equiv.), ligand $\mathrm{L} 2$ (26.8 mg, $0.0750 \mathrm{mmol}, 0.250$ equiv.), $\mathrm{ZnBr}_{2}(67.5 \mathrm{mg}, 0.300$ mmol, 1.00 equiv.), and $\mathrm{NiBr}_{2}$.DME ( $18.5 \mathrm{mg}, 0.0600 \mathrm{mmol}, 0.200$ equiv) were placed into a $25 \mathrm{~mL}$ Schlenk tube. To this vial was added $5.0 \mathrm{~mL}$ of anhydrous DME/diglyme $(v / v=1: 1)$. The Schlenk tube was taken out from the glove box and cooled at $-15^{\circ} \mathrm{C}$. $\alpha$-Bromo-4-methoxycarbonylbenzyl trifluoromethyl 1a $(89.1 \mathrm{mg}$, $0.300 \mathrm{mmol}$ ) was added and the mixture was stirred at $-15^{\circ} \mathrm{C}$ for $12 \mathrm{~h}$. The mixture was quenched by addition of water $(5.0 \mathrm{~mL})$ and extracted with $\mathrm{Et}_{2} \mathrm{O}(10.0 \mathrm{~mL} \times 3)$. The organic layer was combined, dried over anhydrous $\mathrm{Na}_{2} \mathrm{SO}_{4}$ and concentrated under vacuum. The crude product was purified by column chromatography on silica gel with pentane/ethyl acetate as the eluent to give (S)-methyl 4-(2,2,2trifluoro-1-phenylethyl)benzoate $3 \mathbf{a}$ as a yellow liquid (77\% yield, $96: 4$ e.r.).

\section{Data availability}

Experimental procedures and characterization data are available within this article and its Supplementary Information. Data are also available from the corresponding author on request. The X-ray crystallographic coordinates for structures reported in this study have been deposited at the Cambridge Crystallographic Data Center (CCDC), under deposition numbers 1868035 and 1898246 . These data can be obtained free of charge from The Cambridge Crystallographic Data Center via www.ccdc.cam.ac.uk/ data_request/cif.

Received: 22 February 2019 Accepted: 28 May 2019

Published online: 04 July 2019

\section{References}

1. Glorius, F. Asymmetric cross-coupling of non-activated secondary alkyl halides. Angew. Chem. Int. Ed. 47, 8347 (2008).

2. Iwasaki, T., Kambe, N. \& Ni-Catalyzed, C. -C. Coupling using alkyl electrophiles. Top. Curr. Chem. (Z.) 373, 66 (2016).

3. Fu, G. C. Transition-metal catalysis of nucleophilic substitution reactions: a radical alternative to $\mathrm{S}_{\mathrm{N}} 1$ and $\mathrm{S}_{\mathrm{N}} 2$ processes. ACS Cent. Sci. 3, 692 (2017).

4. Choi, J. \& Fu, G. C. Transition metal-catalyzed alkyl-alkyl bond formation: another dimension in cross-coupling chemistry. Science 356, eaaf7230 (2017).

5. Fisher, C. \& Fu, G. C. Asymmetric nickel-catalyzed negishi cross-couplings of secondary a-bromo amides with organozinc reagents. J. Am. Chem. Soc. 127, 4594 (2005).

6. Lou, S. \& Fu, G. C. Nickel/bis(oxazoline)-catalyzed asymmetric kumada reactions of alkyl electrophiles: cross-couplings of racemic a-bromoketones. $J$. Am. Chem. Soc. 132, 1264 (2010).

7. Arp, F. O. \& Fu, G. C. Catalytic enantioselective negishi reactions of racemic secondary benzylic halides. J. Am. Chem. Soc. 127, 10482 (2005).

8. Binder, J. T., Cordier, C. J. \& Fu, G. C. Catalytic enantioselective crosscouplings of secondary alkyl electrophiles with secondary alkylmetal nucleophiles: negishi reactions of racemic benzylic bromides with achiral alkylzinc reagents. J. Am. Chem. Soc. 134, 17003 (2012).

9. Song, S. \& Fu, G. C. Nickel-catalyzed asymmetric negishi cross-couplings of secondary allylic chlorides with alkylzincs. J. Am. Chem. Soc. 130, 2756 (2008).

10. Jiang, X. -J. \& Gandelman, M. Enantioselective suzuki cross-couplings of unactivated 1-fluoro-1- haloalkanes: synthesis of chiral $\beta-, \gamma-, \delta$-, and $\varepsilon$ fluoroalkanes. J. Am. Chem. Soc. 137, 2542 (2015).

11. Owston, N. A. \& Fu, G. C. Asymmetric alkyl-alkyl cross-couplings of unactivated secondary alkyl electrophiles: stereoconvergent suzuki reactions of racemic acylated halohydrins. J. Am. Chem. Soc. 132, 11908 (2010). 
12. Lu, Z., Wilsily, A. \& Fu, G. C. Stereoconvergent amine-directed alkyl-alkyl suzuki reactions of unactivated secondary alkyl chlorides. J. Am. Chem. Soc 133, 8154 (2011)

13. Schmidt, J., Choi, J., Liu, A. T., Slusarczyk, M. \& Fu, G. C. A general, modular method for the catalytic asymmetric synthesis of alkylboronate esters. Science 354, 1265 (2016).

14. Lou, S. \& Fu, G. C. Enantioselective alkenylation via nickel-catalyzed crosscoupling with organozirconium reagents. J. Am. Chem. Soc. 132, 5010 (2010).

15. Saito, B. \& Fu, G. C. Enantioselective alkyl-alkyl suzuki cross-couplings of unactivated homobenzylic halides. J. Am. Chem. Soc. 130, 6694 (2008).

16. Dai, X., Strotman, N. A. \& Fu, G. C. Catalytic asymmetric hiyama crosscouplings of racemic a-bromo esters. J. Am. Chem. Soc. 130, 3302 (2008).

17. Caeiro, J., Sestelo, J. P. \& Sarandeses, L. A. Enantioselective nickel-catalyzed cross-coupling reactionsof trialkynylindium reagents with racemic secondary benzyl bromides. Chem. Eur. J. 14, 741 (2008).

18. Fang, H. et al. Transmetal-catalyzed enantioselective cross-coupling reaction of racemic secondary benzylic bromides with organoaluminum reagents. Org. Lett. 18, 6022 (2016)

19. Varenikov, A. \& Gandelman, M. Synthesis of chiral $\alpha$-trifluoromethyl alcohols and ethers via enantioselective hiyama cross-couplings of bisfunctionalized electrophiles. Nat. Commun. 9, 3566 (2018).

20. Suzuki, A. Organoboron compounds in new synthetic reactions. ACC Chem. Res. 15, 178 (1982)

21. Hall, D. G. Boronic Acids: Preparation and Applications in Organic Synthesis and Medicine. (Wiley-VCH, Weinheim, 2005).

22. Fyfe, J. W. B. \& Watson, A. J. B. Recent developments in organoboron chemistry: old dogs, new tricks. Chem 3, 31 (2017).

23. Zhou, J. \& Fu, G. C. Suzuki cross-couplings of unactivated secondary alkyl bromides and iodides. J. Am. Chem. Soc. 126, 1340 (2004).

24. Huang, W. -C., Wan, X. -L. \& Shen, Q. Enantioselective construction of trifluoromethoxylated stereogenic centers by a nickel-catalyzed asymmetric suzuki-miyaura coupling of secondary benzyl bromides. Angew. Chem. Int. Ed. 56, 11986 (2017).

25. Hagmann, W. K. The many roles for fluorine in medicinal chemistry. J. Med. Chem. 51, 4359 (2008)

26. Purser, S., Moore, P. R., Swallow, S. \& Gouverneur, V. Fluorine in medicinal chemistry. Chem. Soc. Rev. 37, 320 (2008).

27. Zhou, Y. et al. Next generation of fluorine-containing pharmaceuticals, compounds currently in phase II-III clinical trials of major pharmaceutical companies: new structural trends and therapeutic areas. Chem. Rev. 116, 422 (2016).

28. Meanwell, N. A. Fluorine and fluorinated motifs in the design and application of bioisosteres for drug design. J. Med. Chem. 61, 5822 (2018).

29. Brambilla, M. \& Tredwell, M. Palladium-catalyzed Suzuki-Miyaura crosscoupling of secondary a-(trifluoromethyl)benzyl tosylates. Angew. Chem. Int. Ed. 56, 11981 (2017).

30. Budnikova, Y. H., Vicic, D. A. \& Klein, A. Exploring mechanisms in Ni terpyridine catalyzed $\mathrm{C}-\mathrm{C}$ cross-coupling reactions-a review. Inorganics $\mathbf{6}, 18$ (2018).

31. Procter, R. J. et al. A zinc catalyzed $\mathrm{C}\left(\mathrm{sp}^{3}\right)-\mathrm{C}\left(\mathrm{sp}^{2}\right)$ Suzuki-Miyaura cross-coupling reaction mediated by aryl-zincates. Chem. Eur. J. 23, 15889 (2017).

32. Anderson, T. J. \& Vicic, D. A. Direct observation of noninnocent reactivity of $\mathrm{ZnBr}_{2}$ with alkyl halide complexes of nickel. Organometallics 23, 623 (2004).

33. Ma, J. -A. \& Cahard, D. Asymmetric fluorination, trifluoromethylation, and perfluoroalkylation reactions. Chem. Rev. 104, 6119 (2004).

34. Ma, J. -A. \& Cahard, D. Update 1 of: asymmetric fluorination, trifluoromethylation, and perfluoroalkylation reactions. Chem. Rev. 108, PR1 (2008)

35. Nie, J., Guo, H. -C., Cahard, D. \& Ma, J. -A. Asymmetric construction of stereogenic carbon centers featuring a trifluoromethyl group from prochiral trifluoromethylated substrates. Chem. Rev. 111, 455 (2011).
36. Yang, X. Y., Wu, T., Phipps, R. J. \& Toste, F. D. Advances in catalytic enantioselective fluorination, Mono-, Di-, and trifluoromethylation, and trifluoromethylthiolation reactions. Chem. Rev. 105, 826 (2015).

37. Liang, Y. \& Fu, G. C. Stereoconvergent negishi arylations of racemic secondary alkyl electrophiles: differentiating between a $\mathrm{CF}_{3}$ and an alkyl group. J. Am. Chem. Soc. 137, 9523 (2015).

38. Banik, S. M., Medley, J. W. \& Jacobsen, E. N. Catalytic, asymmetri difluorination of alkenes to generate difluoromethylated stereocenters. Science 353, 51 (2016).

39. Bos, M. et al. Catalytic enantioselective synthesis of highly functionalized difluoromethylated cycloprapanes. Angew. Chem. Int. Ed. 56, 13319 (2017).

40. Gehling, V. S. et al. Discovery, design and synthesis of indole-based EZH2 inhibitors. Bioorg. Med. Chem. Lett. 25, 3644 (2015).

41. Sessler, C. D. et al. J. $\mathrm{CF}_{2} \mathrm{H}$, a hydrogen bond donor. J. Am. Soc. Chem. 139, 9325 (2017).

42. Allison, B. D., Carruthers, N. I., Letavic, M. A., Santillan, J. A. \& Shan, C. R. Substituted benzamide modulators of the histamine $\mathrm{H} 3$ receptor. WO2008002816A1. 2008-01-03 (2008).

\section{Acknowledgements}

This work was supported by National Natural Science Foundation of China (21625206, 21632009, 21572258, 21421002) and the Strategic Priority Research Program of the Chinese Academy of Sciences (XDB20000000).

\section{Author contributions}

W.C.H. performed the experiments. M.H. conducted the experiments related monofluoromethylated substrates. X.L.W. participated in the determination of enantioselectivity. Q.L.S. supervised the project. Q.L.S. and W.C.H. co-wrote the manuscript.

\section{Additional information}

Supplementary Information accompanies this paper at https://doi.org/10.1038/s41467 019-10851-4.

Competing interests: The authors declare no competing interests.

Reprints and permission information is available online at http://npg.nature.com/ reprintsandpermissions/

Peer review information: Nature Communications thanks the anonymous reviewer(s) for their contribution to the peer review of this work. Peer reviewer reports are available

Publisher's note: Springer Nature remains neutral with regard to jurisdictional claims in published maps and institutional affiliations.

Open Access This article is licensed under a Creative Common Attribution 4.0 International License, which permits use, sharing, adaptation, distribution and reproduction in any medium or format, as long as you give appropriate credit to the original author(s) and the source, provide a link to the Creative Commons license, and indicate if changes were made. The images or other third party material in this article are included in the article's Creative Commons license, unless indicated otherwise in a credit line to the material. If material is not included in the article's Creative Commons license and your intended use is not permitted by statutory regulation or exceeds the permitted use, you will need to obtain permission directly from the copyright holder. To view a copy of this license, visit http://creativecommons.org/ licenses/by/4.0/

(C) The Author(s) 2019 